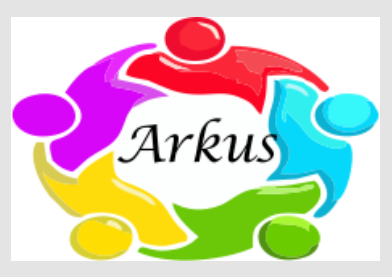

\title{
ARKUS
}

Journal Homepage:

https://hmpublisher.com/index.php/arkus

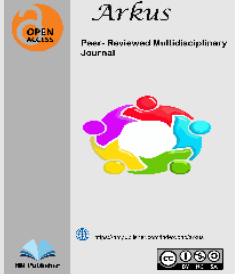

\section{Cupping Therapy Benefit in Glucose Blood Level}

\section{Rara Inggarsih ${ }^{*}$}

${ }^{1}$ Department of Biology, Faculty of Medicine, Universitas Sriwijaya, Palembang, Indonesia

\section{A R T I C L E I N F O}

\section{Keywords:}

Cupping therapy

Insulin receptor

Diabetes mellitus

Blood glucose

\section{Corresponding author:}

Rara Inggarsih

E-mail address:

\section{rarainggarsih@gmail.com}

The author has reviewed and approved the final version of the manuscript.

\begin{abstract}
A B S T R A C T
Some Muslims have used cupping therapy and occupies a popular position among other alternative therapeutic methods. Modern medical research evidence also confirms the benefits of the therapy recommended by the Prophet. Many medical experts know the efficacy of cupping therapy in treating disease. According to the International Diabetes Federation (IDF), in 2013, Indonesia was ranked seventh with diabetes. Cupping therapy plays a role in stimulating blood circulation in the muscles, thereby increasing the metabolism of nutrients and glucose consumption by the muscles. The increased sensitivity of insulin receptors was helping to reduce blood glucose levels. This effect is like the effect of exercise and physical activity on blood glucose levels. This study aims to determine the effect of cupping therapy on blood glucose levels.
\end{abstract}

https://doi.org/10.37275/arkus.v7i2.96

\section{Introduction}

Cupping therapy is a widely used treatment method and is classified in alternative medicine and is gaining popularity worldwide. Several countries that have practised cupping therapy include Egypt, India, China, Saudi Arabia, Germany, Norway, and Denmark. The people of Germany and Denmark, and Norway are already familiar with cupping therapy. This is due to a changing view of the conventional health care system and contemporary medicine. A recent study aimed to evaluate the scientific effectiveness of the technique used in cupping, which is suction and expulsion of blood after making shallow incisions in the skin at various specific points on the body. This therapy is claimed to successfully treat various disorders, such as carpal tunnel syndrome and non-specific low back pain. According to Sharaf, cupping therapy, better known in Indonesia as cupping therapy, occupies a favoured position in the ranks of various other therapeutic methods in various countries because many medical experts know the efficacy of cupping therapy in treating various diseases. ${ }^{1-3}$

Cupping therapy has also been used to prevent several diseases, including diseases of the musculoskeletal system such as fibromyalgia and fibrositis, pain in the spine, pain in the neck and 
shoulders, cardiovascular diseases such as hypertension, atherosclerosis, hypotension, gastrointestinal diseases such as diarrhoea, irritable bowel syndrome, intoxication, medicine and food, autoimmune diseases such as rheumatoid arthritis, and vitiligo. The existence of various diseases that can be prevented by cupping therapy carried out in European and Middle Eastern countries makes researchers interested in researching cupping therapy conducted in Indonesia, and researchers are interested in researching the benefits of cupping therapy in lowering blood glucose levels due to cases of the number of people with diabetes mellitus in Indonesia is increasing every year. 4,5

The latest data from the Indonesian Cupping Therapy Association (ITBI) in 2014 shows that there were 3342 members registered as cupping therapists, increasing every year in Indonesia. Health Clinic data (2014), there are 38 branches of Healthy Clinics and Healthy Therapy Homes throughout Indonesia that practice cupping therapy. In 2011 there were only 14 branches. These data indicate that public demand for cupping therapy as an alternative treatment in Indonesia is increasing. This community request requires cupping therapists to prioritize the sterility of tools and materials and carry out the therapy based on the established SOP. 6-10

The desire to be healthy is a desire that humans always hope for and want to maintain. One type of disease that attacks the community is a degenerative disease. One of the causes of degenerative diseases is the disruption of the body's biochemical homeostasis, such as blood glucose levels. Diabetes mellitus is a disease that is directly related to blood glucose levels. Diabetes mellitus is a disease characterized by an increase in blood glucose levels due to a disturbance in insulin production or the non-absorption of insulin by its receptors or both factors simultaneously.

Data from the International Diabetes Federation (IDF) in 2013 showed that 382 million people were suffering from diabetes mellitus worldwide, and
Indonesia was ranked seventh in the world with 8.5 million people. The Indonesian Ministry of Health in Riskesdas 2013 contains data on the prevalence of people diagnosed and have symptoms of diabetes reaching $2.1 \%$ of the entire population of Indonesia, which means there are 5 million people. Many diabetes mellitus patients in Indonesia make it possible for people to try various alternative treatments such as cupping therapy. ${ }^{11}$

Several studies that tested the effectiveness of cupping therapy in lowering blood glucose levels have been conducted in Indonesia. One example is a study conducted by Subkhi in 2009 on 15 respondents with diabetes mellitus. The study obtained results from an analysis using a paired t-test, namely $\mathrm{p}<0.05$, which showed that there was a difference in blood glucose levels after cupping therapy (mean score $243 \mathrm{mg} / \mathrm{dl}$ ) compared to before cupping therapy (mean score 243 $\mathrm{mg} / \mathrm{dl})$.

Prophet Muhammad SAW. has given many suggestions about cupping therapy through his hadith, "Healing is in three things, namely drinking honey, cupping treatment and burning with fire. Verily, I forbid my ummah (to seek treatment) with fire" (H.R. Bukhârî). "Indeed, the most ideal method of treatment for you is hijama and fashdu (venesection)" (H.R. Bukhâr and Muslim). "On the night I was scattered, I did not pass by a group of angels, but they said, 'O Muhammad, tell your people to perform hijama." (H.R. Ibn Majâh and Ab Dâwûd). "If the medicine you are using contains something good, then it is cupping." (H.R. Abu Dawûd and Ibn Mâjah). According to Sharaf, cupping therapy plays a role in stimulating blood circulation in the muscles, thereby increasing nutrient metabolism and increasing glucose consumption by muscles. The sensitivity of insulin receptors increases, thereby helping to reduce blood glucose levels. This effect is like the effect of exercise and physical activity on blood glucose levels. 


\section{History of cupping therapy}

Cupping therapy has been known to ancient nations since the Sumerian kingdom was founded, about 4,000 years BC. Then cupping therapy developed in Babylon, Egypt, Saba 'and Persia. At that time, the healers used cupping therapy for the treatment of the kings. Well-known physicians only passed on their knowledge of medicine to selected students. Cupping therapy in China developed around 2,500 years BC, before the reign of Emperor Yao and developed based on acupuncture points.3,5

There are many reliefs illustrating cupping therapy in religious buildings of the Pharaoh (Pharaoh) dynasty. Each nation has a different cupping therapy method. Since ancient times, some tribes have used animal horns as a means of sucking blood by punching holes in the tips of the horns, sucking air from the inside and plugging them with paste. They call it horn therapy. ${ }^{13}$

The Romans and Greeks used glass cups for the practice of cupping therapy. They light a fire in a glass that has been filled with a piece of cloth for suction. Many ordinary people still use this method today. Some people use specific equipment that is connected to a tube filled with water and a glass pipe. They heat the water so that it releases water vapour and air from the glass.

Since $1550 \mathrm{BC}$, cupping has been known as a prevalent and vital traditional medicine by the Egyptian people. This is evidenced by the documentation of cupping techniques on papyrus sheets found near the Nile. Cupping therapy developed and spread traditionally to Greece and Rome. Even the grouping of cupping into wet and dry cupping has been carried out by Hippocrates, who is known as the father of modern medicine

In the Asian region, the cupping treatment method is also known in the medical tradition. Cupping has been used since $2 \mathrm{BC}$ in China. In an old book written by Bo Shu, who lived during the Han Dynasty in 1973, there are also writings on the method of cupping treatment. Around the 18-19 century $\mathrm{AD}$, cupping then developed to the West and the American continent. Doctors used cupping to treat various patient conditions until 1860. The popularity of cupping began to decline after 1860 but did not disappear completely. Cupping spread to the Middle East and was then prescribed by the Prophet Muhammad. The treatise of cupping then spread throughout the world along with the spread of Islamic teachings.

The origin of cupping therapy is still controversial. Chinese scientists reported in their literature that cupping therapy had been a part of traditional Chinese medicine since 2000 years ago. Arab writers report that cupping therapy dates back to $3500 \mathrm{BC}$, where the Assyrians were the first Arab population to use this device in the Middle East from animal horns or bamboo sticks for cupping therapy where the Chinese doctor, Jee Hong (381-281 BC) was a figure in the art of medicine.18 Arab civilization called cupping therapy al-hijâmah (in Arabic, it means to return to its original size), used in treating hypertension, polycythemia, headache, migraine and drug poisoning. They diagnosed polycythemia when a pink agglomeration of the skin was found. Interestingly, venesection (phlebotomy) is still used in hospitals today to treat polycythemia, in which blood is removed and replaced by intravenous fluids.

The ancient Egyptians reportedly practised cupping therapy before any old civilization, where cupping therapy was one of the oldest known medical therapies in ancient Egypt. The first reports of the use of cupping therapy in ancient Egypt were in 1550 BC, found in drawings on Egyptian papyrus sheets and ancient Egyptian temples. This shows that the Egyptians had advanced in treatment using cupping therapy. Cupping therapy was also used in ancient Greek medicine.

In $400 \mathrm{BC}$, Herodotus discovered that ancient Egyptian doctors who recommended using suction cups on the body had used both wet and dry cupping 
therapy. Diseases that are treated are headache, lack of appetite, impaired absorption of food, fainting, evacuation of abscesses, and narcolepsy (recurrent urge to sleep). In $3300 \mathrm{BC}$, in Macedonia, cupping therapy has been used since prehistoric times to treat diseases and health disorders.

\section{Types of cupping therapy}

According to Sharaf and Ridho, there are nine cupping therapy treatment methods or cupping therapy that can be done, first light cupping, namely light suction using cupping glasses. The second cupping is (moderate cupping), which is medium suction using cupping glasses. The third cupping is strong (strong cupping), which is strong suction using cupping glasses. The fourth is moving cupping, namely moving the cupping glass after suctioning on the patient's body that has been given lubricating ingredients to avoid strong friction, such as olive oil. The fifth cupping needle (needle cupping), cupping combined with acupuncture, is cupping glass on top of acupuncture needles. The sixth is bleeding, or wet cupping (bleeding cupping), suctioning with cupping glasses after the incision is made. The seventh is herbal cupping, namely by boiling several herbal ingredients intended as medicine together with bamboo cups for cupping, then cupping is done in the usual way. The herbs will move into the patient's body. The eighth cupping water (water cupping) uses water vapour to empty the air from the cupping glass. The ninth magnetic cupping (magnetic cupping). Socalled because of the magnet in the cupping glass that helps the movement of electromagnetic forces in the body. ${ }^{1-2}$

\section{Effects of cupping therapy on disease}

Cupping therapy has a good effect on healing a disease. These diseases are gout, diabetes, coronary heart disease, bronchitis and bronchial asthma, and sinusitis. Many other diseases can be cured through cupping, but the following will be discussed only these diseases.

\section{Effects of cupping on gout}

Cupping can remove uric acid crystals from the joints and surrounding tissue to reduce the pain, and there is no inflammation, redness, or swelling in the joints. All of these symptoms will decrease gradually; through the substance nitric oxide (NO) serves to reduce swelling of painful joints; Cupping can remove prostaglandins from the sore, thereby reducing pain; Cupping can trigger the release of endorphins and enkephalins in the body as a natural analgesic; Cupping can relieve pain with gate control theory; if there are other problems in the body, which are the cause of gout, such as kidney disease, cupping therapy helps increase the kidney's ability to excrete uric acid crystals in the urine. ${ }^{3,4}$

\section{Effects of cupping on diabetes}

Diabetes is closely related to high levels of glucose in the blood. There are many effects of cupping on diabetes and indirectly affect blood glucose levels. The effects in question are that cupping plays a role in stimulating blood circulation and supplying nutrients to beta cells in the pancreas. Cupping also controls insulin production (hyperinsulinism), which occurs in people with type 1 diabetes and causes excess insulin (hyperinsulinism) as occurs in people with type 2 diabetes. Blood circulation in the pancreas and affects controlling insulin levels. The strong suction in the cupping process plays a role in removing intestinal metabolic waste substances from the portal circulation in the liver to increase metabolic processes in the liver and reduce sugar levels. The suction power in the cupping process releases various acids (hexosamines) from the muscles and tissue under the skin, thereby paving the way for insulin to attach to its receptors and increasing insulin receptors' sensitivity, thereby reducing insulin sugar levels. Cupping plays a role in stimulating blood circulation in the muscles, thereby 
increasing the metabolism of nutrients and increasing the consumption of glucose by the muscles. The sensitivity of insulin receptors will increase, which will help reduce sugar levels. This is exactly like the effect of exercise and physical activity on blood sugar levels. ${ }^{5}$

\section{The effect of cupping on blockage of coronary blood vessels}

The effect of cupping on coronary artery blockage is that cupping reduces levels of fat and low-density lipoprotein in the blood and those that settle on the walls of blood vessels and increases blood supply to the heart muscle. Cupping increases the blood supply to the endothelium, which plays a role in producing nitric oxide substances that help widen and stretch the muscles of the coronary blood vessel walls and reduce spasms. The production of nitric oxide (NO) is due to the stimulation of the cupping process, which has several functions, namely the dilation of blood vessels, thereby increasing the blood supply to the heart muscle and increasing its ability and assisting the angiogenesis process so that it plays a role in increasing the supply of blood and nutrients to various parts of the body exposed to attacks through alternative routes. ${ }^{6}$

\section{Effects of cupping on bronchitis and bronchial asthma}

The effect of cupping on bronchitis and bronchial asthma is that nitric oxide (NO) has a role in stimulating blood circulation in the lungs, thereby helping to overcome bronchial muscle spasms and reducing inflammation of the bronchial mucosa external. Cupping plays a role in reducing the production of mucus that causes blockage in the bronchi and increases ciliary movement and mucus discharge.

\section{Effects of cupping on sinusitis}

The effect of cupping on sinusitis is that cupping plays a role in improving blood circulation in the sinus area, sucking stagnant blood from the sinus area to the surface of the skin, thereby reducing inflammation and blockage; cupping plays a role in increasing white blood cells in patients who have a deficiency of white blood cells, and collects them around the area of infection so that it will work to kill bacteria that cause inflammation; nitric oxide (NO) has a role in increasing the effectiveness of antibiotics against bacteria that cause inflammation so that the symptoms of sinusitis will disappear; Cupping plays a role in increasing immunity in general, so that the body's ability to deal with bacterial attacks increases. $^{7}$

\section{Pathophysiological process on blood glucose level Insulin secretion mechanism}

Insulin is a hormone produced by the beta cells of the pancreas gland, consisting of a series of amino acids. If beta cells are stimulated under normal conditions, insulin is synthesized and then secreted into the blood according to the body's needs for blood glucose regulation. Physiologically good regulation of blood glucose is regulated together with the hormone glucagon, which is secreted by the alpha cells of the pancreas gland.

Insulin is in a physiological state, secreted according to normal body requirements by beta cells in two phases so that the secretion is biphasic. This normal biphasic insulin secretion will occur after a stimulus such as glucose from food or drink. The insulin produced functions to regulate blood glucose regulation so that it is always within physiological limits, both during fasting and after receiving a load. The two phases of insulin secretion that occur in synchrony keep blood glucose levels within normal limits to reflect physiological glucose metabolism.

Phase 1 secretion (acute insulin secretion response) is insulin secretion that occurs immediately after stimulation of pancreatic beta cells, appears quickly and ends quickly. Phase 2 secretion 
is activated after phase 1 secretion ends (sustained phase, latent phase), where insulin secretion increases slowly and persists relatively long. Phase 2 secretion will generally proceed with normal phase 1 performance, accompanied by regular insulin action in tissues (without insulin resistance). ${ }^{8,9}$

\section{Effects of insulin metabolism on blood glucose levels}

The presence of disturbances, both of insulin production and action, causes disturbances in glucose metabolism, with various consequences. This stems from an obstacle in glucose utilization, followed by an increase in blood glucose levels. The disorder is clinically known as the symptoms of diabetes mellitus. Disorders of glucose metabolism are caused by two main factors, namely inadequate insulin secretion (insulin deficiency) and lack of sensitivity of body tissues to insulin (insulin resistance), accompanied by environmental factors (environment) in type 2 diabetes mellitus (DMT2) most frequently found. Metabolic disorders caused by absolute insulin deficiency are found in type 1 diabetes. 10

The performance of phase 1 initially determined the course of DMT2 disease, namely insulin secretion that was not as needed, which then harmed the performance of phase 2, namely a condition called Impaired Glucose Tolerance was detected and resulted directly in an increase in blood glucose levels (hyperglycemia). Hyperglycemia occurs not only due to impaired insulin secretion (insulin deficiency) but at the same time also by the inadequate response of body tissues to insulin (insulin resistance). Disturbances or environmental influences such as lifestyle or obesity will accelerate the progression of the disease. Disorders of glucose metabolism will continue to interfere with fat and protein metabolism and the process of damage to various body tissues. A series of disorders caused by insulin resistance, apart from intolerance to glucose and its consequences, often causes a collection of symptoms known as metabolic syndrome. ${ }^{11,12}$

\section{Conclusion}

Cupping therapy (hijama) is helpful in lowering blood glucose levels in diabetes mellitus.

\section{References}

1. Kementerian Kesehatan Republik Indonesia (Kemenkes RI). Riskesdas. http:// depkes. go.id/index.php?vw=2\&id=MCN .201412300 01.

2. Sampanis C. Management of Hypoglycemia in Patient with Diabetes Mellitus and Chronic Renal Failure, Hipocratia. 2008.

3. Eisenberg, DM, et al., "Results of a Follow up National Survey: Trends in Alternative Medicine Use in the United States. JAMA. 1998; 6(3); 150-8.

4. Guyton, A.C., dan J.E. Hall, Buku Ajar Fisiologi Kedokteran. Jakarta: EGC, 2006.

5. HS, Mahmoud, et al., "Anatomical Sites for Practicing Wet Cupping Therapy (alhijamah): in Light of Modern Medicine and Prophetic Medicine. Altern Integ Med. 2013; $8(2)$.

6. LM, Rukzan, dan al-Sabawy DO, "Effect of Wet Cupping on Serum Lipids Profile Levels of Hyperlipidemic Patients and Correlation With Some Metal Ions. Raf Journal Science. 2012.

7. M. Bilal Khan, R.A, et al., "Partial Evaluation of Technique Used in Cupping Therapy," dalam Journal of Basic and Applied Sciences. 2011; 1(VII)

8. Manzhûr, Ibn. Lisân al-'Arab. Beirut: Dâ̂ alFikr, 1994.

9. Misaroh, Siti. Pengaruh Terapi Bekam Terhadap Kadar Glukosa Darah pada Pasien Hipertensi di Klinik an-Nahl Purwokerto. Semarang: Universitas Jenderal Soedirman 
Press. 2008.

10. Murray, RK., et al. Biokimia Harper. Jakarta: EGC. 2006.

11. Mustpha, MBZ. Perbedaan Perubahan Kadar Glukosa Darah Antara Sebelum Mulai Belajar dan Sebelum Waktu Istirahat Pada
Siswa SMA Mulia yang Sarapan dan Tidak Sarapan. Medan: Universitas Sumatera Utara Press. 2010.

12. Price, S.A., dan LM. Wilson. Patofisiologi: Konsep Klinis Proses-proses Penyakit. Jakarta: EGC. 2003. 